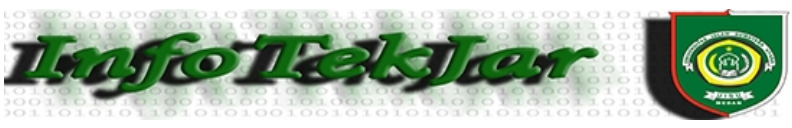

\title{
PENERAPAN DATAMINING PADA POPULASI DAGING AYAM RAS PEDAGING DI INDONESIA BERDASARKAN PROVINSI MENGGUNAKAN K-MEANS CLUSTERING
}

\author{
Mhd Gading Sadewo ${ }^{1}$, Agus Perdana Windarto ${ }^{2}$, Dedy Hartama ${ }^{3}$ \\ ${ }^{1}$ Mahasiswa Sistem Informasi, STIKOM Tunas Bangsa Pematangsiantar \\ ${ }^{2,3}$ Dosen STIKOM Tunas Bangsa Pematangsiantar \\ ${ }^{1,2,3}$ Jln. Jenderal Sudirman Blok A No.1/2/3 Pematangsiantar \\ Gading.sadewooo@gmail.com,aguspw@stikomtb.ac.id,dedyhartama@amiktunasbangsa.ac.id
}

\begin{abstract}
Abstrak- Ayam bukanlah makanan yang asing bagi penduduk Indonesia. Makanan tersebut sangat mudah dijumpai dalam kehidupan masyarakat sehari-hari. Namun tingkat konsumsi daging ayam di Indonesia masih tergolong rendah dibandingkan dengan Negara tetangga. Penelitian ini membahas tentang Penerapan Datamining Pada Populasi Daging Ayam Ras Pedaging di Indonesia Berdasarkan Provinsi Menggunakan KMeans Clustering. Sumber data penelitian ini dikumpulkan berdasarkan dokumen-dokumen keterangan populasi daging ayam yang dihasilkan oleh Badan Pusat Statistik Nasional. Data yang digunakan dalam penelitian ini adalah data dari tahun 2009-2016 yang terdiri dari 34 provinsi. Variable yang digunakan (1) jumlah populasi dari tahun 2009-2016. Data akan diolah dengan melakukan clushtering dalam 3 clushter yaitu clusther tingkat populasi tinggi, clusther tingkat populasi sedang dan rendah. Centroid data untuk cluster tingkat populasi tinggi 4711403141, Centroid data untuk cluster tingkat populasisedang 304240647, dan Centroid data untuk cluster tingkat populasi rendah 554200. Sehingga diperoleh penilaian berdasarkan indeks populasi daging ayam dengan 1 provinsi tingkat populasi tinggi yaitu Jawa Barat, 6 provinsi tingkat populasi sedang yaitu Sumatera Utara, Jawa Tengah, Jawa Timur, Banten, Kalimantan Selatan dan Kalimantan Timur, dan27 provinsi lainnya termasuk tingkat populasi rendah. Hal ini dapat menjadi masukan kepada pemerintah, provinsi yang menjadi perhatian lebih pada populasi daging ayam berdasarkan cluster yang telah dilakukan.
\end{abstract}

Kata Kunci - Clustering, K-Means, Data Mining, Populasi, Ayam Ras Pedaging.

\section{P ENDAHULUAN}

Kebutuhan manusia akan protein hewani sangat besar, rata-rata konsumsi negara maju dan berkembang lebih dari $20 \mathrm{~kg}$ perkapita pertahun. Singapura dan Malaysia sendiri rata-rata konsumsi daging masyarakatnya adalah28 kg perkapita pertahun dan $36 \mathrm{~kg}$ perkapita pertahun, jauh dari Indonesia yang rata-rata konsumsi daging masyarakatnya hanya $4,11 \mathrm{~kg}$ perkapita pertahun. Konsumsi protein hewani berkaitan dengan tingkat intelektualitas dan perkembangan seseorang[1].

Analisis klaster merupakan suatu teknik multivariat dengan tujuan utamamengelompokkan objek-objek berdasarkan karakteristik yang dimiliki. Sekarang ini analisis klaster telah banyak diaplikasikan dalam berbagai bidang yang ditulis dalam berbagai penelitian dan jurnal [2]. Dalam metode clustering konsep utama yang ditekankan adalah pencarian pusat cluster secara iteratif, dimana pusat cluster ditentukan berdasarkan jarak minimum setiap data pada pusat cluster [3]. Data yang digunakan dalam penelitian ini berdasarkan dokumen-dokumen yang dihasilkan oleh Badan Pusat Statistik Nasional melalui situs https://www.bps.go.id. Dalam hal ini peneliti mengangkat topik populasi ayam ras pedaging menurut provinsi dimana proses metode yang dilakukan adalah clustering. Hasil dari cluster dapat dijadikan masukan bagi pemerintah agar provinsi yang masuk kedalam clushter rendah mendapat perhatian lebih. Proses clushter dibagi kedalam 3 (tiga) cluster yakni populasi ekspor tertinggi, populasi ekspor sedang dan populasi ekspor rendah.

\section{TINJAUAN PUSTAKA}

A. Ayam Pedaging (broiler)

Ayam broiler adalah istilah yang dipakai untuk menyebut ayam hasil budidaya teknologi yang memiliki karakter ekonomi dengan ciri khas pertumbuhan cepat, penghasil daging dengan konversi pakan irit dan siap potong pada usia relatif muda. Ayam broiler pada umumnya siap dipotong pada usia 35-45 hari[4]. 


\section{B. Data Mining}

Data Mining adalah proses yang mempekerjakan satu atau lebih teknik pembelajaran computer (machine learning) unutuk menganalisis dan mengekstraksi pengetahuan (knowledge) secara otomatis[5].

\section{Clushtering}

Analisis Pengelompokan / Clustering merupakan proses membagi data dalam suatu himpunan ke dalam beberapa kelompok yang kesamaan datanya dalam suatu kelompok lebih besar daripada kesamaan data tersebut dengan data dalam kelompok lain. Potensi clustering adalah dapat digunakan untuk mengetahui struktur dalam data yang dapat dipakai lebih lanjut dalam berbagai aplikasi secara luas seperti klasifikasi, pengolahan gambar, dan pengenalan pola[6].

\section{K-Means}

K-Means merupakan salah satu metode pengelompokan data nonhierarki (sekatan) yang berusaha mempartisi data yang ada ke dalam bentuk dua atau lebih kelompok. Metode ini mempartisi data ke dalam kelompok sehingga data berkarakteristik sama dimasukkan ke dalam satu kelompok yang sama dan data yang berkarakteristik berbeda dikelompokkan kedalam kelompok yang lain. Adapun tujuan pengelompokkan data ini adalah untuk meminimalkan fungsi objektif yang diatur dalam proses pengelompokan, yang pada umumnya berusaha meminimalkan variasi di dalam suatu kelompok dan memaksimalkan variasi antar kelompok[7].

\section{METODE PENELITIAN}

Dalam penelitian ini metode yang digunakan yaitu metode Data Mining sebagai berikut :

(a) Tahap pengumpulan data,

(b) Tahap pengolahan data,

(c) Tahap Clustering dan

(d) Tahap Analisis

\section{A. Tahap Pengumpulan Data}

Dalam penerapan Data Mining populasidaging ayam berdasarkan provinsi, diperlukan data terkait tentang hal itu. Sumber data penelitian diperoleh dari data yang dikumpulkan berdasarkan dokumen-dokumen keterangan pertanian yang dihasilkan oleh Direktorat Jenderal Bea dan Cukai melalui situs https://www.bps.go.id.

Data yang digunakan dalam penelitian ini adalah data Populasi Daging Ayam Ras Pedaging pada setiap provinsi dari tahun 2009-2016 yang terdiri dari 34 provinsi. Varibale yang digunakan (1) jumlah populasi daging ayam yang sudah diakumulasikan. Data akan diolah dengan melakukan clustering populasi daging ayam berdasarkan provinsi dalam 3 cluster yakni cluster tingkat populasi tinggi, cluster tingkat populasi sedang dan cluster tingkat populasi rendah.

\section{B. Tahap Pengolahan Data}

Data yang telah diperolah akan diolah terlebih dahulu untuk dapat diclustering. Dalam tahap sebelumnya, data setiap provinsi akan dijumlah setiap aspeknya sehingga pada tahapan ini sudah diperoleh perhitungan nilai yang akan diproses pada tahap clustering.

\section{Tahap Clustering}

Clustering merupakan klasifikasi tanpa pengawasan dan merupakan proses partisi sekumpulan objek data dari satu set menjadi beberapa kelas. Hal ini dapat dilakukan dengan menerapkan berbagai persamaan dan langkah-langkah mengenai jarak algoritma, yaitu dengan Euclidean Distance [9]. Analisis kluster ialah metode yang dipakai untuk membagi rangkaian data menjadi beberapa grup berdasarkan kesamaan-kesamaan yang telah ditentukan sebelumnya [8]. Dalam menentukan cluster berdasarkan data yang telah tersedia, dibutuhkan sebuah flowchart untuk memudahkan dalam menentukan alur perhitungan sebagai alur untuk menemukan hasil dari penerapan cluster terhadap data yang akan diproses. Berikut adalah flowchart dalam menentukan cluster dengan K-Means [5].

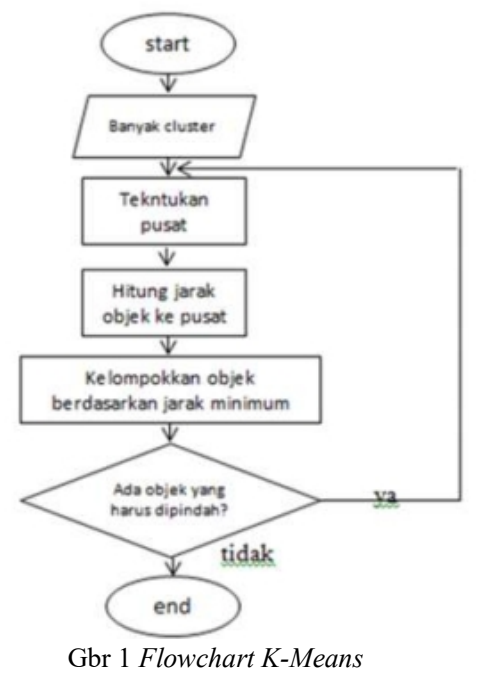

\section{Tahap Analisis}

Pada tahapan ini dilakukan analisis datapopulasi daging ayam ras pedaging. Data yang diperoleh diolah dengan menggunakan perhitungan bobot dari tiap indeks. Pada tahapan sebelumnya, telah ditentukan akan dicluster ke dalam 3 cluster yakni cluster tingkat populasi tinggi, cluster tingkat 
populasisedang dan cluster tingkat populasirendah. Pada tahapan inilah akan dianalisis hasilnya.

\section{HASIL DAN PEMBAHASAN}

Dalam melakukan clustering, data yang diperoleh akan dihitung terlebih dahulu berdasarkan jumlah populasi daging ayam ras pedaging pada tahun 2009-2016 berdasarkan provinsi. Hasil penjumlahan berdasarkan 1 kriteria penilaian yakni jumlah populasiseperti yang ditunjukkan pada tabel 1 .

TABEL I

DATA POPULASI AYAM RAS PEDAGING MENURUT PROVINSI

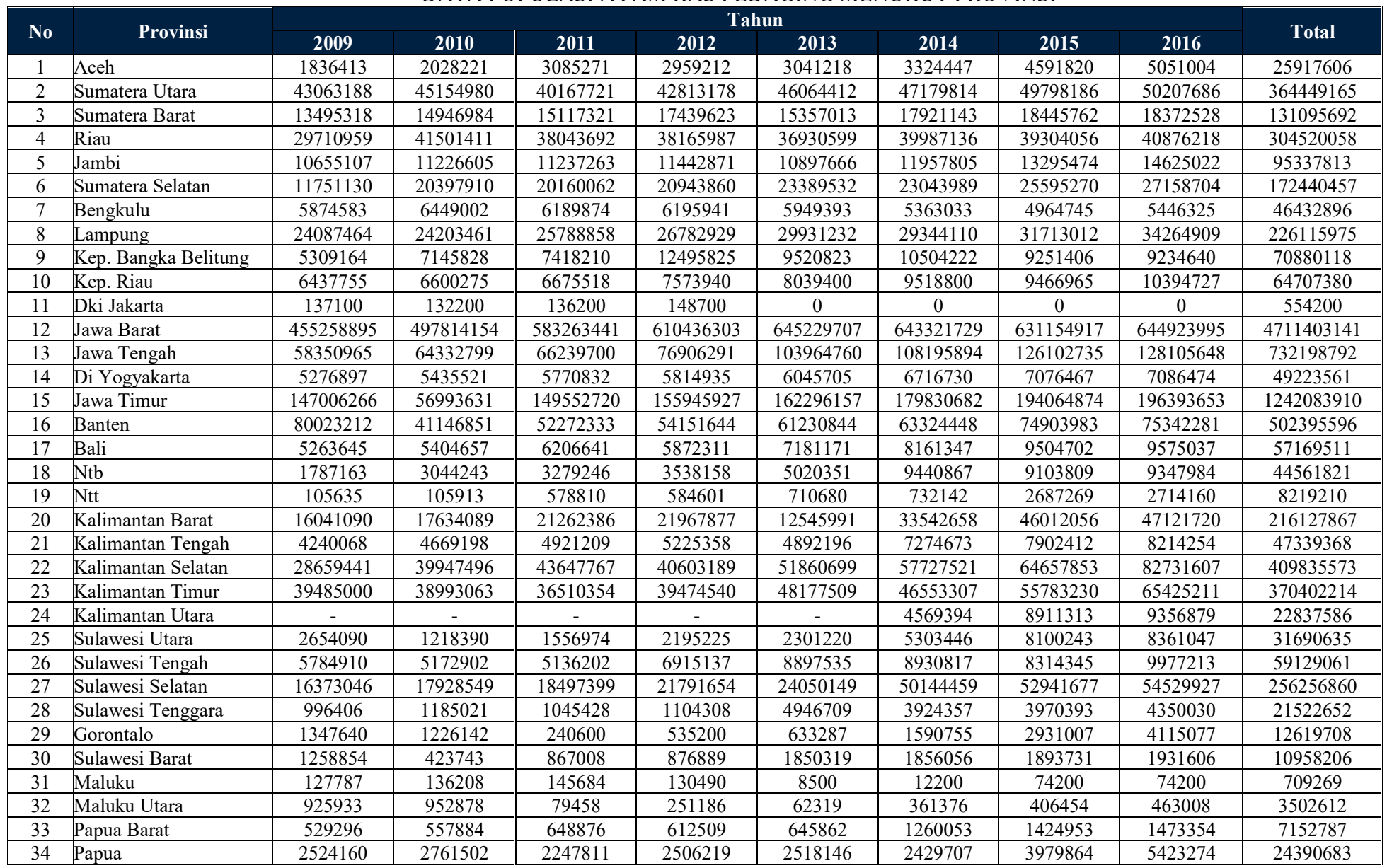

Sumber : Badan Pusat Statistik, url :https://www.bps.go.id

Data tersebut kemudian diakumulasikan berdasarkan 1 kriteria yaitu jumlah populasi seperti yang ditunjukkan pada tabel 2 berikut:
TABEL II

DATA AKUMULASI POPULASI AYAM RAS PEDAGING

\begin{tabular}{|c|l|c|}
\hline No & \multicolumn{1}{|c|}{ Provinsi } & $\begin{array}{c}\text { Jumlah Populasi } \\
\text { Ayam Ras Pedaging }\end{array}$ \\
\hline 1 & Aceh & 25917606 \\
\hline 2 & Sumatera Utara & 364449165 \\
\hline 3 & Sumatera Barat & 131095692 \\
\hline 4 & Riau & 304520058 \\
\hline 5 & Jambi & 95337813 \\
\hline
\end{tabular}




\begin{tabular}{|c|c|c|}
\hline No & Provinsi & Jumlah Populasi \\
\hline 6 & Sumatera Selatan & 172440457 \\
\hline 7 & Bengkulu & 46432896 \\
\hline 8 & Lampung & 226115975 \\
\hline 9 & Kep. Bangka Belitung & 70880118 \\
\hline 10 & Kep. Riau & 64707380 \\
\hline 11 & Dki Jakarta & 554200 \\
\hline 12 & Jawa Barat & 4711403141 \\
\hline 13 & Jawa Tengah & 732198792 \\
\hline 14 & Di Yogyakarta & 49223561 \\
\hline 15 & Jawa Timur & 1242083910 \\
\hline 16 & Banten & 502395596 \\
\hline 17 & Bali & 57169511 \\
\hline 18 & Nusa Tenggara Barat & 44561821 \\
\hline 19 & Nusa Tenggara Timur & 8219210 \\
\hline 20 & Kalimantan Barat & 216127867 \\
\hline 21 & Kalimantan Tengah & 47339368 \\
\hline 22 & Kalimantan Selatan & 409835573 \\
\hline 23 & Kalimantan Timur & 370402214 \\
\hline 24 & Kalimantan Utara & 22837586 \\
\hline 25 & Sulawesi Utara & 31690635 \\
\hline 26 & Sulawesi Tengah & 59129061 \\
\hline 27 & Sulawesi Selatan & 256256860 \\
\hline 28 & Sulawesi Tenggara & 21522652 \\
\hline 29 & Gorontalo & 12619708 \\
\hline 30 & Sulawesi Barat & 10958206 \\
\hline 31 & Maluku & 709269 \\
\hline 32 & Maluku Utara & 3502612 \\
\hline 33 & Papua Barat & 7152787 \\
\hline 34 & Papua & 24390683 \\
\hline
\end{tabular}

Setelah diakumulasikan maka akan didapatkan nilai dari seluruh populasi ayam ras pedaging menurut provinsi. Kemudian data tersebut akan masuk ke tahapan clustering dengan menerapkan algoritma K-Means untuk mengcluster data menjadi tiga cluster.

\section{A. Centroid Data}

Dalam penerapan algoritma $K$-means dihasilkan nilai titik tengah atau centroid dari data yang didapat dengan ketentuan bahwa clusterisasi yang diinginkan adalah 3, Penentuan cluster dibagi atas tiga bagian yakni cluster tingkat populasi tinggi $(\mathrm{C} 1)$, cluster tingkat populasisedang $(\mathrm{C} 2)$ dan cluster tingkat populasirendah (C3). maka nilai titik tengah atau centroid juga terdapat 3 titik. Penentuan titik cluster ini dilakukan dengan mengambil nilai terbesar (maksimum) untuk cluster tingkat populasitinggi $(\mathrm{C} 1)$, nilai rata-rata (average) untuk cluster tingkat populasisedang (C2) dan nilai terkecil (minimum) untuk cluster tingkat populasirendah (C3). Nilai titik tersebut dapat diketahui pada Tabel 3 berikut:

TABEL III

CENTROID DATA AWAL

\begin{tabular}{|l|c|c|c|}
\hline Atribut & $\begin{array}{c}\text { Cluster } \\
\text { populasitinggi }\end{array}$ & $\begin{array}{c}\text { Cluster } \\
\text { populasisedang }\end{array}$ & $\begin{array}{c}\text { Cluster } \\
\text { populasirendah }\end{array}$ \\
\hline Nilai & 4711403141 & 304240647 & 554200 \\
\hline
\end{tabular}

\section{B. Clustering Data}

Dengan menggunakan centroid tersebut maka dapat dicluster data yang telah didapat menjadi 3 cluster. Proses cluster dengan mengambil jarak terdekat dari setiap data yang diolah. Dari data populasi ayam ras pedaging menurut provinsi didapatkan pengelompokan pada iterasi 1 untuk 3 cluster tersebut. Cluster tingkat populasi tinggi (C1) yakni Jawa Barat, cluster tingkat populasisedang (C2) yakni Sumatera Utara, Riau, Sumatera Selatan, Lampung, Jawa Tengah, Jawa Timur, Banten, Kalimantan Selatan, Kalimantan Selatan, Kalimantan Timur, dan Sulawesi Selatan dan cluster tingkat populasirendah (C3) yakni 22 provinsi lainnya . Proses pencarian jarak terpendek, pengelompokan data pada iterasi 1 dan Clustering data dapat digambarkan pada tabel dan gambar berikut:

TABEL IV

PERHITUNGAN JARAK PUSAT CLUSTER

\begin{tabular}{|c|l|c|c|c|c|c|}
\hline \multicolumn{1}{|c|}{ No Provinsi } & $\begin{array}{c}\text { Jlh Populasi Ayam } \\
\text { Ras Pedaging }\end{array}$ & C1 & C2 & C3 & $\begin{array}{c}\text { Jarak } \\
\text { Terpendek }\end{array}$ \\
\hline 1 & Aceh & 25917606 & 4685485535 & 278323041 & 25363406 & 25363406 \\
\hline 2 & Sumatera Utara & 364449165 & 4346953976 & 60208518 & 363894965 & 60208518 \\
\hline 3 & Sumatera Barat & 131095692 & 4580307449 & 173144955 & 130541492 & 130541492 \\
\hline 4 & Riau & 304520058 & 4406883083 & 279411 & 303965858 & 279411 \\
\hline 5 & Jambi & 95337813 & 4616065328 & 208902834 & 94783613 & 94783613 \\
\hline 6 & Sumatera Selatan & 172440457 & 4538962684 & 131800190 & 171886257 & 131800190 \\
\hline 7 & Bengkulu & 46432896 & 4664970245 & 257807751 & 45878696 & 45878696 \\
\hline 8 & Lampung & 226115975 & 4485287166 & 78124672 & 225561775 & 78124672 \\
\hline 9 & Kep. Bangka Belitung & 70880118 & 4640523023 & 233360529 & 70325918 & 70325918 \\
\hline 10 & Kep. Riau & 64707380 & 4646695761 & 239533267 & 64153180 & 64153180 \\
\hline 11 & Dki Jakarta & 554200 & 4710848941 & 303686447 & 0 & 0 \\
\hline
\end{tabular}




\begin{tabular}{|c|l|c|c|c|c|c|}
12 & Jawa Barat & 4711403141 & 0 & 4407162494 & 4710848941 & 0 \\
\hline 13 & Jawa Tengah & 732198792 & 3979204349 & 427958145 & 731644592 & 427958145 \\
\hline 14 & Di Yogyakarta & 49223561 & 4662179580 & 255017086 & 48669361 & 48669361 \\
\hline 15 & Jawa Timur & 1242083910 & 3469319231 & 937843263 & 1241529710 & 937843263 \\
\hline 16 & Banten & 502395596 & 4209007545 & 198154949 & 501841396 & 198154949 \\
\hline 17 & Bali & 57169511 & 4654233630 & 247071136 & 56615311 & 56615311 \\
\hline 18 & Nusa Tenggara Barat & 44561821 & 4666841320 & 259678826 & 44007621 & 44007621 \\
\hline 19 & Nusa Tenggara Timur & 8219210 & 4703183931 & 296021437 & 7665010 & 7665010 \\
\hline 20 & Kalimantan Barat & 216127867 & 4495275274 & 88112780 & 215573667 & 88112780 \\
\hline 21 & Kalimantan Tengah & 47339368 & 4664063773 & 256901279 & 46785168 & 46785168 \\
\hline 22 & Kalimantan Selatan & 409835573 & 4301567568 & 105594926 & 409281373 & 105594926 \\
\hline 23 & Kalimantan Timur & 370402214 & 4341000927 & 66161567 & 369848014 & 66161567 \\
\hline 24 & Kalimantan Utara & 22837586 & 4688565555 & 281403061 & 22283386 & 22283386 \\
\hline 25 & Sulawesi Utara & 31690635 & 4679712506 & 272550012 & 31136435 & 31136435 \\
\hline 26 & Sulawesi Tengah & 59129061 & 4652274080 & 245111586 & 58574861 & 58574861 \\
\hline 27 & Sulawesi Selatan & 256256860 & 4455146281 & 47983787 & 255702660 & 47983787 \\
\hline 28 & Sulawesi Tenggara & 21522652 & 4689880489 & 282717995 & 20968452 & 20968452 \\
\hline 29 & Gorontalo & 12619708 & 4698783433 & 291620939 & 12065508 & 12065508 \\
\hline 30 & Sulawesi Barat & 10958206 & 4700444935 & 293282441 & 10404006 & 10404006 \\
\hline 31 & Maluku & 709269 & 4710693872 & 303531378 & 155069 & 155069 \\
\hline 32 & Maluku Utara & 3502612 & 4707900529 & 300738035 & 2948412 & 2948412 \\
\hline 33 & Papua Barat & 7152787 & 4704250354 & 297087860 & 6598587 & 6598587 \\
\hline 34 & Papua & 24390683 & 4687012458 & 279849964 & 23836483 & 23836483 \\
\hline
\end{tabular}

TABEL V

PENGELOMPAKAN DATA ITERASI 1

\begin{tabular}{|c|l|c|c|c|}
\multirow{2}{*}{ No } & \multicolumn{1}{c}{ Provinsi } & \multicolumn{2}{c|}{ Kelompok Data 1 } \\
\cline { 2 - 4 } & Aceh & & & 1 \\
\hline 2 & Sumatera Utara & & 1 & \\
\hline 3 & Sumatera Barat & & 1 & 1 \\
\hline 4 & Riau & & & 1 \\
\hline 5 & Jambi & & 1 & \\
\hline 6 & Sumatera Selatan & & 1 & \\
\hline 7 & Bengkulu & & & 1 \\
\hline 8 & Lampung & & & 1 \\
\hline 9 & Kep. Bangka Belitung & & & 1 \\
\hline 10 & Kep. Riau & 1 & & \\
\hline 11 & Dki Jakarta & & 1 & \\
\hline 12 & Jawa Barat & & & 1 \\
\hline 13 & Jawa Tengah & & 1 & \\
\hline 14 & Di Yogyakarta & & 1 & \\
\hline 15 & Jawa Timur & & & 1 \\
\hline 16 & Banten & & & 1 \\
\hline 17 & Bali & & & 1 \\
\hline 18 & Nusa Tenggara Barat & & 1 & \\
\hline 19 & Nusa Tenggara Timur & & & 1 \\
\hline 20 & Kalimantan Barat & & 1 & \\
\hline 21 & Kalimantan Tengah & & 1 & \\
\hline 22 & Kalimantan Selatan & & & 1 \\
\hline 23 & Kalimantan Timur & & & 1 \\
\hline 24 & Kalimantan Utara & & \\
\hline 25 & Sulawesi Utara & & 1 \\
\hline 26 & Sulawesi Tengah & & \\
\hline 27 & Sulawesi Selatan & & \\
\hline 28 & Sulawesi Tenggara & & & \\
\hline 29 & Gorontalo & & & 1 \\
\hline 30 & Sulawesi Barat & & & \\
\hline & & & & \\
\hline
\end{tabular}

\begin{tabular}{|l|l|l|l|l|}
31 & Maluku & & & 1 \\
\hline 32 & Maluku Utara & & & 1 \\
\hline 33 & Papua Barat & & & 1 \\
\hline 34 & Papua & & & 1 \\
\hline
\end{tabular}

\section{Jumlah Populasi Ayam Ras Pedaging}

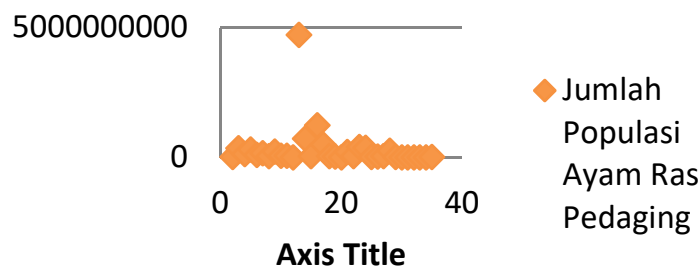

Gbr 2 Clusthering Data 


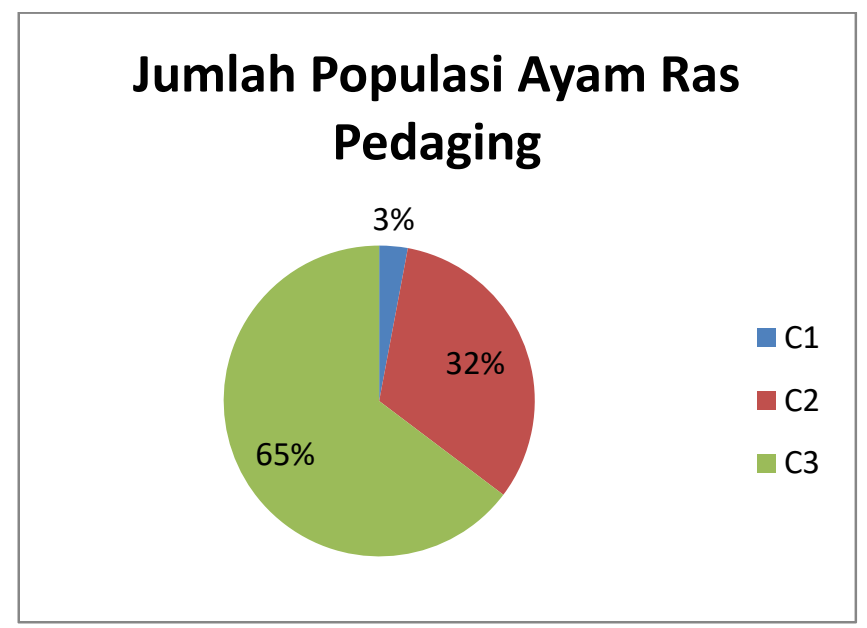

Gbr 3 Clusthering Data

Proses K-Means akan terus beriterasi sampai pengelompokan data sama dengan pengelompokan data iterasi sebelumnya. Dengan kata lain, proses akan terus melakukan iterasi sampai data pada iterasi terakhir sama dengan iterasi sebelumnya.
Pada iterasi 1 diperoleh cluster data populasi ayam ras pedaging berdasarkan provinsi, yang dapat dilihat pada gambar 2.Proses iterasi tersebut berhenti pada iterasi ke 5, pada iterasi 5 akan dilakukan proses mencari nilai titik tengah atau centroid yang dapat diketahui pada Tabel 6 berikut :

TABEL VI

DATA CENTROID ITERASI 5

\begin{tabular}{|c|c|c|c|}
\hline Atribut & $\begin{array}{c}\text { Cluster } \\
\text { populasitinggi }\end{array}$ & $\begin{array}{c}\text { Cluster } \\
\text { populasisedang }\end{array}$ & $\begin{array}{c}\text { Cluster } \\
\text { populasirendah }\end{array}$ \\
\hline Nilai & 4711403141 & 622617378.7 & 74496799.7 \\
\hline
\end{tabular}

Setelah mendapatkan nilai titik tengah atau centroid, proses sama dilakukan dengan mencari jarak terdekat. Proses pencarian jarak terpendek, pengelompokan data pada iterasi 5 dan Clustering data dapat digambarkan pada tabel dan gambar berikut:

TABEL VII

PERHITUNGAN JARAK PUSAT CLUSTER ITERASI 5

\begin{tabular}{|c|c|c|c|c|c|c|}
\hline No & Provinsi & $\begin{array}{c}\text { Jumlah } \\
\text { Populasi } \\
\text { Ayam Ras } \\
\text { Pedaging }\end{array}$ & C1 & $\mathbf{C 2}$ & C3 & $\begin{array}{c}\text { Jarak } \\
\text { Terpendek }\end{array}$ \\
\hline 1 & Aceh & 25917606 & 4685485535 & 596699772.7 & 48579193.7 & 48579193.7 \\
\hline 2 & Sumatera Utara & 364449165 & 4346953976 & 258168213.7 & 289952365.3 & 258168213.7 \\
\hline 3 & Sumatera Barat & 131095692 & 4580307449 & 491521686.7 & 56598892.3 & 56598892.3 \\
\hline 4 & Riau & 304520058 & 4406883083 & 318097320.7 & 230023258.3 & 230023258.3 \\
\hline 5 & Jambi & 95337813 & 4616065328 & 527279565.7 & 20841013.3 & 20841013.3 \\
\hline 6 & Sumatera Selatan & 172440457 & 4538962684 & 450176921.7 & 97943657.3 & 97943657.3 \\
\hline 7 & Bengkulu & 46432896 & 4664970245 & 576184482.7 & 28063903.7 & 28063903.7 \\
\hline 8 & Lampung & 226115975 & 4485287166 & 396501403.7 & 151619175.3 & 151619175.3 \\
\hline 9 & Kep. Bangka Belitung & 70880118 & 4640523023 & 551737260.7 & 3616681.704 & 3616681.704 \\
\hline 10 & Kep. Riau & 64707380 & 4646695761 & 557909998.7 & 9789419.704 & 9789419.704 \\
\hline 11 & Dki Jakarta & 554200 & 4710848941 & 622063178.7 & 73942599.7 & 73942599.7 \\
\hline 12 & Jawa Barat & 4711403141 & 0 & 4088785762 & 4636906341 & 0 \\
\hline 13 & Jawa Tengah & 732198792 & 3979204349 & 109581413.3 & 657701992.3 & 109581413.3 \\
\hline 14 & Di Yogyakarta & 49223561 & 4662179580 & 573393817.7 & 25273238.7 & 25273238.7 \\
\hline 15 & Jawa Timur & 1242083910 & 3469319231 & 619466531.3 & 1167587110 & 619466531.3 \\
\hline 16 & Banten & 502395596 & 4209007545 & 120221782.7 & 427898796.3 & 120221782.7 \\
\hline 17 & Bali & 57169511 & 4654233630 & 565447867.7 & 17327288.7 & 17327288.7 \\
\hline 18 & Nusa Tenggara Barat & 44561821 & 4666841320 & 578055557.7 & 29934978.7 & 29934978.7 \\
\hline 19 & Nusa Tenggara Timur & 8219210 & 4703183931 & 614398168.7 & 66277589.7 & 66277589.7 \\
\hline 20 & Kalimantan Barat & 216127867 & 4495275274 & 406489511.7 & 141631067.3 & 141631067.3 \\
\hline 21 & Kalimantan Tengah & 47339368 & 4664063773 & 575278010.7 & 27157431.7 & 27157431.7 \\
\hline 22 & Kalimantan Selatan & 409835573 & 4301567568 & 212781805.7 & 335338773.3 & 212781805.7 \\
\hline 23 & Kalimantan Timur & 370402214 & 4341000927 & 252215164.7 & 295905414.3 & 252215164.7 \\
\hline 24 & Kalimantan Utara & 22837586 & 4688565555 & 599779792.7 & 51659213.7 & 51659213.7 \\
\hline 25 & Sulawesi Utara & 31690635 & 4679712506 & 590926743.7 & 42806164.7 & 42806164.7 \\
\hline 26 & Sulawesi Tengah & 59129061 & 4652274080 & 563488317.7 & 15367738.7 & 15367738.7 \\
\hline
\end{tabular}




\begin{tabular}{|c|l|c|c|c|c|c|}
27 & Sulawesi Selatan & 256256860 & 4455146281 & 366360518.7 & 181760060.3 & 181760060.3 \\
\hline 28 & Sulawesi Tenggara & 21522652 & 4689880489 & 601094726.7 & 52974147.7 & 52974147.7 \\
\hline 29 & Gorontalo & 12619708 & 4698783433 & 609997670.7 & 61877091.7 & 61877091.7 \\
\hline 30 & Sulawesi Barat & 10958206 & 4700444935 & 611659172.7 & 63538593.7 & 63538593.7 \\
\hline 31 & Maluku & 709269 & 4710693872 & 621908109.7 & 73787530.7 & 73787530.7 \\
\hline 32 & Maluku Utara & 3502612 & 4707900529 & 619114766.7 & 70994187.7 & 70994187.7 \\
\hline 33 & Papua Barat & 7152787 & 4704250354 & 615464591.7 & 67344012.7 & 67344012.7 \\
\hline 34 & Papua & 24390683 & 4687012458 & 598226695.7 & 50106116.7 & 50106116.7 \\
\hline
\end{tabular}

TABEL VIII

PENGELOMPAKAN DATA ITERASI 2

\begin{tabular}{|c|c|c|c|c|}
\hline \multirow{2}{*}{ No } & \multirow{2}{*}{ Provinsi } & \multicolumn{3}{|c|}{ Kelompok Data 5} \\
\hline & & C1 & C2 & C3 \\
\hline 1 & $\mathrm{ACEH}$ & & & 1 \\
\hline 2 & SUMATERA UTARA & & 1 & \\
\hline 3 & SUMATERA BARAT & & & 1 \\
\hline 4 & RIAU & & & 1 \\
\hline 5 & JAMBI & & & 1 \\
\hline 6 & SUMATERA SELATAN & & & 1 \\
\hline 7 & BENGKULU & & & 1 \\
\hline 8 & LAMPUNG & & & 1 \\
\hline 9 & KEP. BANGKA BELITUNG & & & 1 \\
\hline 10 & KEP. RIAU & & & 1 \\
\hline 11 & DKI JAKARTA & & & 1 \\
\hline 12 & JAWA BARAT & 1 & & \\
\hline 13 & JAWA TENGAH & & 1 & \\
\hline 14 & DI YOGYAKARTA & & & 1 \\
\hline 15 & JAWA TIMUR & & 1 & \\
\hline 16 & BANTEN & & 1 & \\
\hline 17 & $\mathrm{BALI}$ & & & 1 \\
\hline 18 & NUSA TENGGARA BARAT & & & 1 \\
\hline 19 & NUSA TENGGARA TIMUR & & & 1 \\
\hline 20 & KALIMANTAN BARAT & & & 1 \\
\hline 21 & KALIMANTAN TENGAH & & & 1 \\
\hline 22 & KALIMANTAN SELATAN & & 1 & \\
\hline 23 & KALIMANTAN TIMUR & & 1 & \\
\hline 24 & KALIMANTAN UTARA & & & 1 \\
\hline 25 & SULAWESI UTARA & & & 1 \\
\hline 26 & SULAWESI TENGAH & & & 1 \\
\hline 27 & SULAWESI SELATAN & & & 1 \\
\hline 28 & SULAWESI TENGGARA & & & 1 \\
\hline 29 & GORONTALO & & & 1 \\
\hline 30 & SULAWESI BARAT & & & 1 \\
\hline 31 & MALUKU & & & 1 \\
\hline 32 & MALUKU UTARA & & & 1 \\
\hline 33 & PAPUA BARAT & & & 1 \\
\hline 34 & PAPUA & & & 1 \\
\hline
\end{tabular}

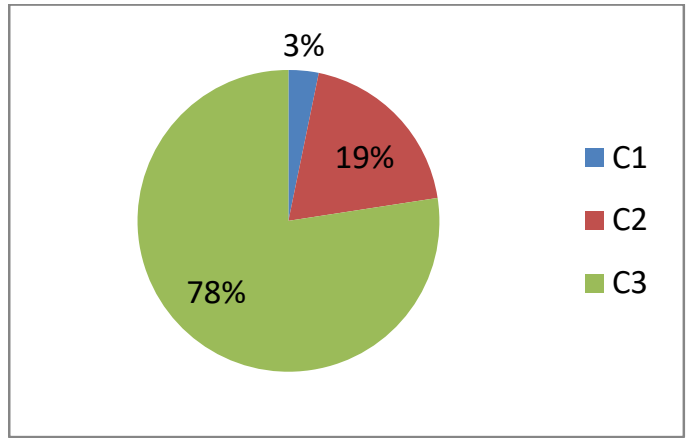

Gbr 3. Clustering Data Iterasi 5

C. Analisa Data

Pada iterasi 5, pengelompokan data yang dilakukan terhadap 3 cluster dengan iterasi 4 didapatkan hasil yang sama. Dari 34 data populasi ayam ras pedaging berdasarkan provinsi dapat dikertahui, 1provinsi cluster tingkat populasi tinggi yakni Jawa Barat, 6provinsi cluster tingkat populasi sedang yakni Sumatera Utara, Jawa Tengah, Jawa Timur, Banten, Kalimantan Selatan dan Kalimantan Timur dan 27provinsi lainnya termasuk cluster tingkat populasi rendah.

\section{KESIMPULAN}

Untuk melakukan penilaian terhadap hasil populasi ayam ras pedaging menurut provinsi dapatmenerapkan metode clustering K-Means. Data diolah untuk memperolah nilai dari populasi ayam ras pedaging menurut provinsi. Data tersebut diolah menggunakan Ms. Excel untuk ditentukan nilai centroid dalam 3 cluster yaitu cluster tingkat populasi tinggi, cluster tingkat populasi sedang dan cluster tingkat populasi rendah. Cetroid data untuk cluster tingkat populasi tinggi 904.276,5, Cetroid data untuk cluster tingkat populasi sedang 265.501 dan Cetroid data untuk cluster tingkat populasi rendah $34.280,1$. Sehingga diperoleh penilaian berdasarkan indeks indeks populasi daging ayam dengan 1 provinsi tingkat populasi tinggi yaitu Jawa Barat, 6 provinsi tingkat populasi sedang yaitu Sumatera Utara, Jawa Tengah, Jawa Timur, Banten, Kalimantan Selatan dan Kalimantan Timur, dan 27 provinsi lainnya termasuk tingkat populasirendah. Hasil yang didapat dari penelitian dapat menjadi masukan kepada pemerintah, provinsi yang menjadi 
perhatian lebih pada populasi daging ayam berdasarkan cluster yang telah dilakukan.

\section{UCAPAN TERIMA KASIH}

Terima kasih kepada program studi sistem informasi, STIKOM Tunas Bangsa Pematangsiantar atas dukungan dalam terlaksanakannya penelitian ini serta bapak pembimbing Agus Perdana Windarto.

\section{DAFTAR PUSTAKA}

[1] (http://www.jurnas.com/halaman/15/2011-10-14/185472, 8 Agustus 2017).

[2] S. M. S. Hadi Rachmat, Anindya Apriliyanti Pravitasari, "Fuzzy KMeans Clustering Untuk Mengklasifikasikan Perusahaan Eksportir Furniture Rotan Di Kabupaten Cirebon," Pros. Semin. Nas. Stat., vol. 2010, no. November, pp. 146-153, 2010 .
[3] S. Nelson Butarbutar, Agus Perdana Windarto, Dedi Hartama, "Komparasi Kinerja Algoritma Fuzzy C-Means Dan K-Means Dalam Pengelompokan Data Siswa Berdasarkan Prestasi Nilai Akademik Siswa," JURASIK (Jurnal Ris. Sist. Inf. Tek. Inform., vol. 1, no. 2012, pp. 46-55, 2016.

[4] Murtidjo, B.A. 1993. Beternak Sapi Potong. Kanisius.Yogyakarta.

[5] Hermawati, F. A., 2013, Data Mining, Penerbit ANDI, Yogyakarta.

[6] Luthfi, Kusrini dan Emha Taufiq. 2009. Algoritma Data Mining. Yogyakarta: Andi.

[7] Prasetyo, Eko. 2012. Data Mining: Konsep dan Aplikasi menggunakan MATLAB. Yogyakarta: CV Andi Offset.

[8] Wyatt, J. C, danSpiegelhalter, D., 1991, Field Trials of Medical Decision-Aids: PotentialProblems and Solutions, Clayton, P. (ed.): Proc. 15th Symposium on ComputerApplications in Medical Care, Vol 1, Ed. 2, McGraw Hill Inc, New York.

[9] Venkateswarlu, B., \& Raju, P. G., 2013, Mine Blood Donors Information through Improved KMeans Clustering, arXiv preprint arXiv:1309.2597. 